\title{
Bakverkir og sýklalyf
}

\section{Ólafur Guðlaugsson}

Sérfræðingur i l lyflækningum og smitsjúkdómum Landspítalanum

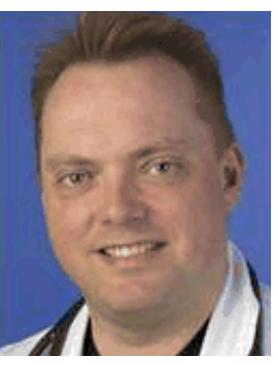

olafgudı@landspitali.is

Í mars síðastliðnum birtist grein í tímaritinu European Spine Journal (ESJ) um notkun á sýklalyfjum við langvarandi bakverkjum hjá sjúklingum með sértækar breytingar (Modic gerð 1) á segulómmyndum¹. Pessi grein hlaut mikla umfjöllun í fjölmiðlum. Í sama tölublaði tímaritsins birtist önnur grein eftir sama hóp par sem sagt var frá pví að merki um bakteríur hefðu fundist í sýnum sem tekin voru úr sjúklingum með brjósklos og hefðu sumir sýnt sömu breytingar við segulómun². Pessar greinar voru kynntar á sérstökum blaðamannafundi í mars par sem jafnvel var látið í veðri vaka að Nóbelsverðlaunin væru innan seilingar. Ritaðir hafa verið leiðarar í Læknablaðið af minna tilefni.

Fyrri greinin ${ }^{1}$ lýsir tvíblindaðri, slembaðri rannsókn sem fjallar um áhrif sýklalyfja hjá sjúklingum með bakverki og Modic 1 breytingar við segulómskoðun. Sjúklingar voru fengnir frá tveimur sérhæfðum bakgöngudeildum í Danmörku. Sjúklingahópnum var skipt í tvennt með slembun; meðferðarhóp og samanburðarhóp. Meðferðarhópurinn fékk amoxicillin/ clavulanic sýru í prjá mánuði. Engin vefjasýni eða ræktanir voru teknar. Sjúklingarnir voru ekki með merki um langvarandi sýkingar í blóðrannsóknum, né heldur próaði neinn peirra alvarlega klíníska sýkingu við 12 mánaða eftirfylgd. Samanburðarhópurinn fékk lyfleysu. Hóparnir voru metnir eftir 100 daga og aftur eftir eitt ár. Í heild voru bornir saman 77 sjúklingar í meðferðarhópnum og 67 sjúklingar í samanburðarhópnum. Í meðferðarhópnum fengu $65 \%$ aukaverkanir vegna sýklalyfjanna og fjórir hættu vegna alvarlegra aukaverkana. Eftir eitt ár var segulómun endurtekin. Pá voru 92\% í meðferðarhópnum og 97\% í samanburðarhópum ennpá með Modic 1 breytingar. Svo virðist sem meðferðarhópurinn hafi almennt verið með umfangsminni Modic breytingar eftir meðhöndlun, en ekki voru bornar saman myndir einstakra sjúklinga fyrir og eftir meðhöndlun. Ekki reyndist marktækur munur milli fjarvista frá vinnu milli hópana. Meðferðarhópurinn virtist vera við betri líðan samkvæmt ýmsum verkjakvörðum, pótt hann væri ennpá með umtalsverð einkenni. Áhugavert er hve lítinn bata samanburðarhópurinn fékk á einu ári.

Í seinni greininni ${ }^{2}$, var spurt hvort sýking íliðpófum í hrygg valdi Modic breytingum. Rannsakaðir voru sjúklingar á göngudeild vegna brjóskloss, alls 61 sjúklingur. Peir fóru allir í aðgerð vegna brjóskloss par sem sýni náðist til ræktunar. Af peim voru 28 með jákvæða ræktun; flestir með Propionibacterium acnes. Pá var metið hverjir í hópnum voru með einhverjar Modic breytingar (óskilgreint). Reyndist pað vera meirihluti hópsins með jákvæðu ræktanirnar, eða 35 á móti 26. Prátt fyrir að höfundar tali um tölfræðilega marktækni milli hópa, var hún fengin á annan hátt en búast hefði mátt við miðað við hönnun rannsóknarinnar. Uppsetning rannsóknarinnar og niðurstöður hennar gera höfundum í raun ekki kleift að svara peirri rannsóknarspurningu sem peir settu fram.

Svokallaðar Modic breytingar í segulómun eru í pessum greinum gerðar að sértækum breytingum fyrir sýkingar. Fjöldi rannsókna hefur metið pessar Modic breytingar og almennt ekki getað staðfest að pær séu sértækar fyrir bakverki, hvað pá sýkingar ${ }^{3}$, sérstaklega í ljósi pess að pær geta horfið án meðferðar'. Pegar stórum hópum af sjúklingum með slæma bakverki og staðfestar Modic breytingar hefur verið fylgt eftir í langan tíma, eru einungis örfáir sem próa með sér hefðbundnar klínískar sýkingar ${ }^{5}$ og pá ekki með P. acnes. Í umræðu um pessar greinar í British Medical Journal $(\mathrm{BMJ})^{6}$ er að auki bent á hagsmunaárekstur sem ekki er gerð grein fyrir í umræddum greinum $^{1,2}$. Tveir höfunda sitja í stjórn fyrirtækis (www.mastmedical.com) sem skráð var um leið og greinin birtist á heimasíðu ESJ í rafrænni útgáfu í febrúar. Petta fyrirtæki gerir út á pað að kenna læknum að tileinka sér og verða "MAST certified doctor" gegn greiðslu. „MAST" stendur fyrir "Modic Antibiotic Spine Therapy“. "MAST" meðhöndlun virðist á heimasíðunni snúast um að nýta pessa nýju meðferðarnálgun segulómun og sýklalyf - til að meðhöndla langvarandi bakverki. Peir læknar sem fá pessa vottun eru síðan auglýstir par sérstaklega. Sjúklingum sem skoða síðuna er hjálpað að finna „MAST certified“ lækna með aðstoð „Google Maps ${ }^{\complement}$ “.

Рað má pví segja að höfundarnir séu í besta falli á hálum ís pegar peir setja fram og kynna með pompi og pragt nýja hugmyndafræði um eðli og orsakir mjóbaksverkja, sem gengur gegn niðurstöðum fjölda rannsókna og viðtekinni pekkingu á sýkingum í beinum. Engar langtímarannsóknir styðja hugmyndir hópsins, hvorki um tilvist, tilurð, gang né árangur peirrar meðferðar sem haldið er á lofti. Pví má ekki gleyma að langtímameðferð með sýklalyfjum er ekki og verður aldrei án aukaverkana fyrir suma sjúklinga og slík meðferð eykur hættu á próun ónæmis í bakteríum. Pví er pörf á vel unnum rannsóknum til að rannsaka betur pær hæpnu niðurstöður sem settar eru fram í pessum greinum. Út frá peim gögnum sem fyrir liggja er alls ekki hægt að mæla með pví að sýklalyf séu notuð til að meðhöndla langvarandi bakverki.

1. Albert HB, Sorensen IS, Christensen BS, Manniche C. Antibiotic treatment in patients with chronic low back pain and vertebral bone edema (Modic type 1 changes): a double-blind randomized clinical controlled trial of efficacy. Eur Spine J 2013;22:697-707.

2. Albert HB, Lambert P, Rollason J, et al. Does nuclear tissue infected with bacteria following disc herniations lead to Modic changes in the adjacent vertebrae? Eur Spine J 2013;22:690-6.

4. Quattrocchi CC, Alexandre AM, Della Pepa GM, Altavilla R, Zobel BB. Modic changes: anatomy, pathophysiology and clinical correlation. Acta Neurochir Suppl 2011;108:4953.

3. Kovacs FM, Arana E, Royuela A, et al. Vertebral Endplate Changes Are Not Associated with Chronic Low Back Pain among Southern European Subjects: A Case Control Study. Am J of Neuroradiol 2012;33:1519-24.

5. Ohtori S, Koshi T, Yamashita M, et al. Existence of pyogenic spondylitis in Modic type 1 change without other signs of infection: 2-year follow-up. Eur Spine J 2010;19:1200-5.

6. McCartney M. Antibiotics for back pain: hope or hype? BMJ 2013;346:f3122. 